\title{
PENGARUH BEBAN KERJA TERHADAP KINERJA SALES PROMOTION DENGAN MOTIVASI SEBAGAI VARIABEL MODERASI DI PT. WORLD INNOVATIVE TELECOMMUNICATIONCABANG SINGARAJA
}

\author{
I Gede Ukas Aksama ${ }^{1}$, Komang Krisna Heryanda ${ }^{2}$, Ni Made Ary Widiastini ${ }^{3}$ \\ ${ }^{1}$ Program Studi Manajemen, Jurusan Manajemen, Fakultas Ekonomi \\ Universitas Pendidikan Ganesha, Singaraja \\ e-mail:igedeukasaksama@gmail.com, krisna.heryanda@gmail.com,ary.widiastini@undiksha.ac.id
}

\begin{abstract}
ABSTRAK
Penelitian ini bertujuan untuk menguji (1) pengaruh beban kerja terhadap kinerja sales promotion, (2) pengaruh beban kerja terhadap kinerja sales promotion dengan motivasi sebagai variabel moderasi. Penelitian ini meggunakan desain kuantitatif kausal. PT. World Innovative Telecommunication merupakan salah satu perusahaan elektronik yang memproduk smartphone dengan merek OPPO.Subjek penelitian ini adalah seluruh karyawan sales promotion PT World Innovative Telecommunication Cabang Singaraja yaitu sebanyak 34 orang. Objek penelitian ini adalah beban kerja terhadap kinerja karyawan sales promotion dengan motivasi sebagai variable moderasi karyawan. Data dikumpulkan dengan menggunakan kuesioner kemudian dianalisis menggunakan analsis moderasi. Hasil penelitian ini menunjukkan bahwa (1)Beban kerja berpengaruh negative dan signifikan terhadap kinerja, menunjukan beban kerja dapat menurunkan kinerja sales promotion.(2) motivasi dapat mempengaruhi beban kerja terhadap kinerja karyawan, yakni motivasi dapat menurunkan beban kerja sehingga meningkatkan kinerja.
\end{abstract}

Kata kunci: Beban Kerja, Kinerja, Motivasi.

Abstract

This Research aims to test (1) The impact of workload on sales promotion performance, (2) the impact of workload on sales promotion performance with motivation as moderation variable. This research used causal quantitative design. PT. World Innovative Telecommunication is one of the electronics company that makes smartphone with OPPO brand. The subject of this research is allemployees Of PT World Innovative Telecommunication, Singaraja branch, which is 34 people. The object of this research is the workload on the employee performance ofales promotion with motivation as variable moderation of employees. Data collected using questionnaires are then analyzed using moderation analysis. The results of this study showed that (1)Negative and significant workload on performance, indicating workload can decrease the performance of Sales promotion. (2) Motivation can affect workload on employee performance, motivation can reduce workload and improve performance.

Keywords: workload, performance, motivation.

\section{Pendahuluan}

PT. World Innovative Telecommunication merupakan salah satu perusahaan elektronik yang memproduk smartphone dengan merek OPPO.Dari tahun 2013 sampai sekarang sejak masuk ke Indonesia sampai saat ini hampir semua orang mengenal produk mereka. Dengan mengedepankan fitur kamera, ketahannan produk OPPO, banyak outlet penjualan serta servis centernya banyak dan tersebar di seluruh indonesia.Untuk tujuan dan kelangsungan dari perusahaan dalam penerapannya dibutuhkan sumber daya manusia.Sebagai salah satu sumber daya perusahaan, sumber daya manusia memiliki peran penting dalam menjalankan perusahaan.Dengan itu dibutuhkan manajemen sumber daya manusia (MSDM). Yang merupakan mengatur hubungan dan peran tenaga kerja sebagai sebuah ilmu dan seni untuk mewujudkan perusahaan maupun masyarakat (Hasibuan, 2012:9).Dengan adanya manajemen 
yang baik, sehingga akan berpengaruh pada kinerja dari karyawan khususnya sales promotion.Dari pendapat Mangkunegara (2006) mengenai kinerja merupakan outcome atau keluaran secara kualitas dan kuantitas serta tanggujawab dalam melaksanakan tugas oleh seorang karyawan. Salah satu fokus MSDM adalah mempertahankan kinerja darisales promotion karena berkaitan dan memiliki peran dalam penjualan produk. Sebab peran dari sales promotionyaitumempromosikan serta menjual produk. Perusahaan bergantung pada penjualan produk untuk dapat mendapatkan mencapai tujuan perusahaan. Oleh sebab itu perusahaan menempatkan target dalam penjualan, sehingga perushaan memberikan target minimum dalam penjualan setiap periode agar perushaan tetap bisa bekerja dengan baik.

Dari target penjualan yang ditetapkan untuk sales promotion yang kurun waktu tertentu tidak mencapai target akan mendapat teguran serta hukuman. Dari penambahan jam kerja sampai berfoto didepan toko pada waktu tertentu dan sebagainya, bila tidak ada perubahan maka akan diganti. Khususnya di cabang Singaraja terjadi penurunan pencapaian target dari penjualan sales promotion disebabkan dominasi penjualan di beberapa outlet didominasi penjualan dari pesaing. Dan penempatan sales promotion di outlet penjualan wilayah Singaraja yang minat pembeliannya rendah. Sehingga terjadinya persaingan sesama antar sales promotion dalam perusahaan dan juga dengansales promotion pesaing. Oleh sebab itu menimbulkan tekanan dalam bekerja, sehingga sales promotion dalam bekerja memiliki beban kerja. Usaha yang dikeluarkan untuk memenuhi permintaan dari pekerjaan dengan kapasitas kerjanya terbatas(Irzal 2016).(Dhani, 2010;16) beban kerja itu sejumlah kegiatan yang membutuhkan proses mental maupun kemampuan dengan bentuk fisik maupun psikis jangka waktu tertentu harus diselesikan.

Didalam perusahaan motivasi dari karyawan juga dapat mempengaruhi dari kinerja karyawan tersebut. Kekuatan untuk mendorong perilaku dari seseorang untuk melakukan tindakan merupakan motivasi, yang mana tingkat motivasi ditentukan ditentukan melaui besarnya intensitas kekuatan dari dalam diri seseorang Widodo (2015). Karena adanya motivasi karyawan akan meningkatkan antusias dan usaha dalam bekerja menjadi lebih keras sehingga dapat memberikan kinerja yang terbaik. Yang dapat meningkatkan motivasi adalah dorongan atau semangat dari atasan dan pemberian pelatihan, serta hadiah atau bonus.Bonusdidapat dari mengumpulkan poin dari produk yang dijual.Karena persaingan antar sales promotion yang mana penempatan berbeda- beda serta juga dengan pesaingmenyebabkan mengumpulkan poin menjadi sulit, sehingga hanya sedikit karyawan yang dapat bonus. Dan bila tidak dapat menjual produk maka akan mendapatkan gaji pokok saja. Pelatihan dandukungan motivasi dari atasan yang masih minim,sehingga lambat laun dari kejadian tersebut membuat motivasi dari sales promotion dalam bekerja menjadi kurang stimulus. Diperparah dengan target penjualan yang tinggi, sehingga membuat membuat sales promotion menjadi kurang dalam motivasi dalam bekerja.

Dari uraian latar belakang masalah diatas, bahwa fenomena yang terjadi pada kinerja para sales promotion di PT. World Innovative Telecommunication Cabang Singaraja dipengaruhi beban kerja dan motivasi. Dari pengaruh beban kerja tinggi serta motivasi rendah dapat mempengaruhi kinerja. Dimana motivasi disini apakah dapat miningkatkan ataupun menurunkan pengaruh beban kerja terhadap kinerja karyawan. Maka dari itu dipandang perlu untuk melakukan penelitian yang berjudul "Pengaruh Beban Kerja Terhadap Kinerja Sales Promotion Dengan Motivasi Sebagai Variabel Moderasi di PT. World Innovative Telecommunicatian Cabang Singaraja". Penelitian ini dilakukan selama bulan Juli sampai Desember 2018

Tujuan dari penelitian ini adalah untuk memperoleh temuan eksplanatif yang teruji tentang pengaruh sebagai berikut. (1) Pengaruh beban kerja terhadap kinerja karyawan PT. World Innovative Telecommunication Cabang Singaraja. (2) Pengaruh motivasi dalam memoderasi hubungan beban kerja dengan kinerja karyawan PT. World Innovative Telecommunication Cabang Singaraja. Adapun hasil dari penelitian diharapkan dapat memberi kontribusi bagi penerapan ilmu ekonomi khususnya dibidang Manajemen Sumber Daya Manusia, dan penelitian ini diharapkan dapat digunakan sebagai bahan referensi bagi penelitian selanjutnya. Secara praktis diharapkan penelitian ini dapat memberikan masukan 
dan kontribusi pemikiran kepada PT. World Innovative Telecommunication Cabang Singaraja, khususnya dalam upaya peningkatan kinerja dengan memperhatikan beban kerja dan motivasi khususnya kepada para karyawan PT. World Innovative Telecommunication Cabang Singaraja agar mampu tercapainya tujuan dan target perusahaan dengan baik dan dengan kurun waktu yang telah ditentukan.

Secara teoritik penelitian ini dilandasi oleh beberapa teori tentang beban kerja, kinerja dan motivasi. Menurut Widodo (2015)kinerja individu adalah bagian hasil dari kinerja baik dari segi kualitas maupun kuantitas berdasarkan standar kerja yang ditentukan. Mangkunegara (2006) kinerja merupakan outcome atau keluaran secara kualitas dan kuantiatas serta tanggujawab dalam melaksanakan tugas oleh seorang karyawan. Dengan ukuran indikator kinerja dapat dikelompokkan dan diambil dua kategori yaitu : (1) kualitas kerja serta (2) kuantitas kerja.Usaha yang dikeluarkan untuk memenuhi permintaan dari pekerjaan dengan kapasitas kerjanya terbatas (Irzal 2016). Dari pendapat Dhani $(2010 ; 16)$ beban kerja itu sejumlah kegiatan yang membutuhkan proses mental maupun kemampuan dengan bentuk fisik maupun pisikis jangka waktu tertentu harus diselesikan. Menurut Putra (2012:22), indikator beban kerja meliputi. (1) Target Yang Harus Dicapai (2) Kondisi (3) Standar (4) Penggunaan Waktu Kerja Rivai, dkk (2013), motivasi adalah serangkaian sikap dan nilai-nilai yang mempengaruhi individu mencapai hal yang spesifik sesuai dengan tujuan individu. Sikap dan nilai tersebut merupakan suatu yang invisible sehingga memberikan kekuatan untuk mendorong individu bertingkah laku dalam mencapai tujuan. Kekuatan untuk mendorong perilaku dari seseorang untuk melakukan tindakan merupakan motivasi, yang mana tingkat motivasi ditentukan ditentukan melaui besarnya intensitas kekuatan dari dalam diri seseorang Widodo (2015). Mengacu pada pendapat Ratna (2015) indikator motivasi (1) gaji yang diberikan (2) rekan kerja (3) kondisi kerja (4) usaha.

Beban kerja memiliki pengaruh terhadap kinerja karyawan, pemberian kerja berelebihi dari kemampuan kerja dari karyawan menimbulakan beban kerja sehingga pada akhirnya mempengaruhi kinerja karyawan itu sendiri. Bahwa beban kerja adalah suatu kompetisi dari suatu sumber mental yang terbatas. Salah satu penyebab menurunnya performa dari beban kerja adalah keharusan untuk mengambil dua atau lebih tugas-tugas yang harus dikerjakan secara bersamaan. Semakin banyaknya permintaan untuk melaksanakan tugas-tugas tersebut maka semakin berkurangnya performa dalam bekerja dari pendapat Sunyoto (2012:114). Serta diperkuat penelitian Fitri (2018:43), beban kerja menurut karyawan sendiri pun berbeda-beda, apabila individu tersebut memiliki persepsi yang positif maka mereka menganggap sebagai tantangan. Dan jika persepsi negatif mereka yang muncul beban kerja dianggap sebagai tekanan, beban kerja yang dimaksud adalah kapasitas seseorang karyawan yang terbatas dalam melakukan pekerjaan tertentu. Disini menurut pendapat diatas beban kerja dapat berpengaruh terhadap kinerja, artinya kinerja dapat menurun ketika dipengaruhi oleh beban kerja yang tinggi.

$\mathrm{H}_{1}$ : Terdapat pengaruh signifikan beban kerja terhadap kineja sales promotion di PT. World Innovative Telecommunication Cabang Singaraja.

Hubungan motivasi apakah dapat mempengaruhi hubungan antara beban kerja terhadap kinerja. Dari pendapat Manuaba (2000) faktor internal dalam beban kerja meliputi faktor somatic (jenis kelamin, umur, dan kondisi kesehatan) serta faktor Psikis (motivasi, kepercayaan, prestasi, keinginan dan kepuasan). Menunjukkan bahwa dari beban kerja yang ada akan menimbulkan dampak psikis yaitu salah satunya dapat mempengaruhi motivasi sehingga berdampak pada kinerja karyawan. Membuat adanya hubungan antara motivasi terhadap beban kerja melalui pengaruh dari dalam diri. Menurut Morgan dan Michael (1993), yang mengemukakan bahwa jika pegawai menghayati pekerjaan sebagai beban kerja sehingga pegawai mengalami ketegangan di dalam pekerjaan karena kemampuannya tidak sesuai dengan tuntutan organisasi hal ini akan berdampak pada perilaku yang ditampilkan oleh pegawai yaitu perilaku tidak efektif dalam bekerja, seperti malas, menghindari tugas atau rendahnya motivasi dan kinerja pegawai. Menurut Adinugroho (2017:02), jika beban kerja terlalu banyak dan tidak sesuai kemampuan karyawan dalam bekerja, maka karyawan tidak akan cupuk memiliki motivasi. Dengan demikian karyawan tidak akan mempunyai motivasi 
kerja sesuai dengan diharapkan perusahaan hal tersebut akan menghambat tercapainya tujuan dari perusahaan tersebut. Sehingga beban kerja yang berlebihan akan menyebabkan kemungkinan motivasi karyawan akan mengalami penurunan sehingga berdampak pada kekinerja karyawan tersebut.

$\mathrm{H}_{1}$ : Adanya pengaruh signifikan motivasi terhadap hubungan beban kerja dengan kineja sales

\section{Metode} promotion di PT. World Innovative Telecommunication Cabang Singaraja.

Penelitian ini menggunakan desain penelitian kuantitatif kausal terdiri dari beberapa tahapan meliputi (1) merumuskan masalah, (2) mengkaji teori, (3) merumuskan hipotesis, (4) mengumpulkan data, (5) mengolah data, dan (6) menarik simpulan. subjek penelitian yang digunakan dalam penelitian ini adalah karyawan bagian sales promotion di PT. World Innovative Telecommunication Cabang Singaraja, sedangkan objek penelitian ini adalah beban kerja, motivasi dan kinerja karyawan sales promotion di PT. World Innovative Telecommunication Cabang Singaraja. Penelitian ini dikategorikan sebagai penelitian populasi karena semua populasi dijadikan sebagai unit pengamatan atau sasaran penelitian yang berjumlah 34 orang. Teknik pengumpulan data dalam penelitian ini yaitu kuesioner, selanjutnya data yang diperoleh akan dianalisis menggunakan alasisis Moderated Regression Analysis. Tujuan dari regresi moderasi adalah untuk mengetahui apakah variabel pemoderasi akan memperkuat atau memperlemah hubungan antara variabel independen dan variabel dependen (Ghozali, 2011). Analisis moderasi digunakan untuk mengatahui apakah variabel motivasi dapat memperkuat atau memperlemah hubungan antar beban kerja dengan kinerja.

\section{Hasil dan Pembahasan}

Hasil

Berdasarkan hasil perhitungan uji statistik Moderated Regression Analysisdengan menggunakan bantuan program Statistical Package for Social Science (SPSS) 17.0 For Windows maka diperoleh hasil perhitungan SPSS tentang Pengaruh masing-masing variabel

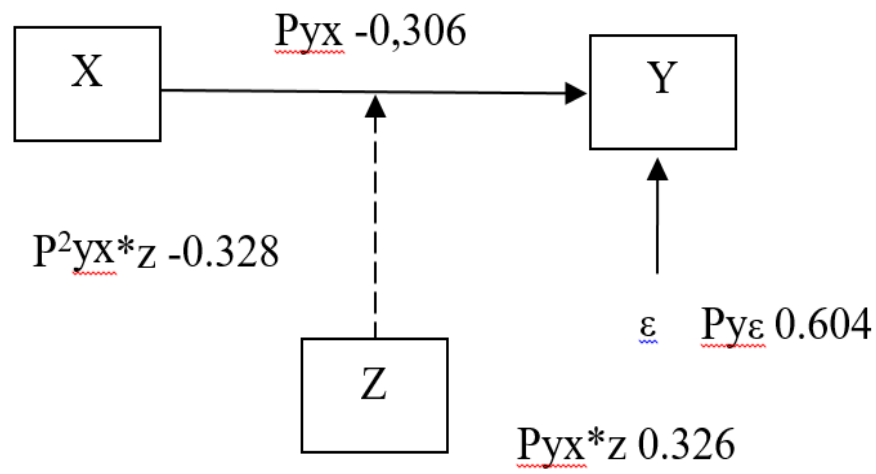

terhadap kinerja sales promotion di PT. World Innovative Telecommunication Cabang Singaraja dapat digambarkan pada.

Gambar 1 Struktur Hubungan $Z$ terhadap $X$ dengan $Y$

Persamaan regresi moderasi menunjukkan bahwa nilai konstanta 3,910 hal ini dapat diartikan variabel bebas, apabila variabel bebas ( $\mathrm{X}-\mathrm{Z}$ ) konstan, maka besaran nilai variabel $(\mathrm{Y})$ adalah 3,910. Sedangkan nilai koefisien regresi beban kerja $(X)$ mempunyai pengaruh negatif sebesar -0,306 terhadap kinerja (Y), artinya semakin tinggi beban kerja yang dialami maka dapat menurunkan kinerja sales promotion. Sedangkan jika ditambah dengan motivasi (Z) maka akan menghasilkan nilai sebesar $-0,328$ terhadap kinerja.

Pengujian hipotesis dilakukan untuk mengatahui pengaruh seluruh variabel independen terhadap variabel dependen untuk melihat pengaruh masing-masing variabel dalam model regresi moderasi yang diperoleh uji t. Beban kerja (X) sebagai independen dan motivasi $(Z)$ sebagai variabel moderating secara individual dalam menerangkan variabel dependen yaitu 
kinerja (Y). (1) Beban kerja berpengaruh negative dan signifikan terhadap kinerja sales promotion pada PT. World Innovative Telecommunication Cabang Singaraja. Hal ini ditunjukkan nilai $\mathrm{t}=2,797$ dengan $p$-valueX $=0,009<\alpha=0,05$. Maka dapat disimpulkan bahwa $\mathrm{H}_{0}$ ditolak dan $\mathrm{H}_{a}$ diterima yang artinya beban kerja memiliki pengaruh signifikan terhadap kinerja. (2) Motivasi berpengaruh positif dan signifikan terhadap hubungan beban kerja dengan kinerja sales promotion pada PT. World Innovative Telecommunication Cabang Singaraja. Hal ini ditunjukkan nilai $t=2,038$ dengan $p$-valueX $=0,031<\alpha=0,05$. Maka dapat disimpulkan bahwa $\mathrm{H}_{0}$ ditolak dan $\mathrm{H}_{a}$ diterima yang artinya motivasi memperlemah dalam memoderasi beban kerja terhadap kinerja. Terjadi juga Moderari semu atau moderator quasi merupakan Variabel yang memoderasi hubungan antara variabel bebas dan variabel terikat, dimana variabel moderasi semu berinteraksi dengan variabel bebas sekaligua menjadi variabel bebas. Yang artinya variabel bebas mempengaruhi variabel terikat serta variabel moderasi yang mempengaruhi hubungan antar variabel sekaligus menjadi variabel bebas, dengan hasil samasama signifikan pada kedua variabel tersebut. Dari persamaan diatas, dengan $p$-valueX= $0,009<\alpha=0,05$ artinya $X$ signifikan dan $p$-valueZ $=0,0097<\alpha=0,05$ artinya signifikan. Sehingga dapat diartikan bahwa variabel moderasi motivasi $Z$ juga menjadi variabel bebas beserta variabel $\mathrm{X}$ karena sama signifikan.

\section{Pembahasan}

Berdasarkan penelitian yang telah dilakukan, maka diperoleh temuan bahwa variabel beban kerja berpengaruh terhadap kinerja salespromotion pada PT. World Innovative TelecommunicationCabang Singaraja. Hasil penelitian ini mendukung teori menurut Menurut Irzal (2016), workload atau beban kerja merupakan usaha yang harus dikeluarkan oleh seseorang untuk memenuhi "permintaan" dari pekerjaan tersebut. serta pendapat Sunyoto (2012:114) menjelaskan bahwa beban kerja adalah suatu kompetisi dari suatu sumber mental yang terbatas. Salah satu penyebab menurunnya performa dari beban kerja adalah keharusan untuk mengambil dua atau lebih tugas-tugas yang harus dikerjakan secara bersamaan. Semakin banyaknya permintaan untuk melaksanakan tugas-tugas tersebut maka semakin berkurangnya performa dalam bekerja. Hal itu dibuktikan dari rendahnya persentase realisasi ketercapaian kinerja salespromotion pada PT. World Innovative TelecommunicationCabang Singaraja sejak bulan Juli sampai dengan Desember 2018. Hal tersebut diakibatkan tingginya beban kerja yang dialami karyawan sales promotion, jika manajemen salespromotion pada PT. World Innovative TelecommunicationCabang Singaraja. dapat mengelola beban kerja dengan baik maka akan dapat memperbaiki kinerja dari karyawan sales promotion.

Hasil penelitian selanjutnya menemukan bahwa motivasi berpengaruh secara positif dan signifikan serta memperlemah hubungan beban kerja dengan kinerja salespromotion pada PT. World Innovative TelecommunicationCabang Singaraja. Oleh teori dari Manuaba (2000), mengatakan faktor internal dalam beban kerja meliputi faktor somatic (jenis kelamin, umur, ukuran tubuh, status gizi dan kondisi kesehatan) serta faktor Psikis (motivasi, prestasi, kepercayaan, keinginan dan kepuasan) serta (Michael G), yang mengemukakan bahwa jika pegawai menghayati pekerjaan sebagai beban kerja sehingga pegawai mengalami ketegangan di dalam pekerjaan karena kemampuannya tidak sesuai dengan tuntutan organisasi hal ini akan berdampak pada perilaku yang ditampilkan oleh pegawai yaitu perilaku tidak efektif dalam bekerja, seperti malas, menghindari tugas atau rendahnya motivasi dan kinerja pegawai. Turut mendukung hasil penelitian ini adalah Adinugroho (2017:02), jika beban kerja terlalu banyak dan tidak sesuai dengan kemampuan karyawan, maka karyawan tidak akan mempunyai motivasi kerja sesuai dengan kemapuan karyawa. Pengaruh tingkat motivasi sales promotion dapat menurunkan pengaruh hubungan beban kerja dengan kinerja karyawan sales promotion, sehingga motivasi yang kurang harus ditingkatkan denga sebaik mungkin agar segala kemungkinan buruk yang ditimbulkan akibat beban kerja karyawan dapat teratasi lebih dini, untuk mengelola beban kerja dan meningkatkan motivasi dapat dilakukan dengan melakukan pendekatan secara individu dan bisa juga dengan pendekatan secara organisasi.

\section{Simpulan dan Saran Simpulan}

Berdasarkanhasildan pembahasan yangtelah dilakukan,maka dapat ditarik beberapa 
simpulan sebagai berikut.

(1) Beban kerja berpengaruh negatif dan signifikan terhadap kinerja kinerja salespromotionpada PT. World Innovative TelecommunicationCabang Singaraja. Semakin tinggi beban kerja para sales promotion, maka akan berdampak pada menurunnya kinerja para sales promotion.

(2) Pengaruh motivasi terhadap hubungan beban kerja dengan kinerja kolektor salespromotion pada PT. World Innovative TelecommunicationCabang Singaraja. Semakin rendah motivasi dan dengan beban kerja yang tinggi, maka akan menurunkan kinerja dari para sales promotion.

\section{Saran}

Berdasarkan hasil, pembahasan, dan simpulan, maka dapat diajukan beberapasaran sebagaiberikut.

(1) Bagi pihak manajemen PT. World Innovative TelecommunicationCabang Singaraja,agarlebihmeningkatkankinerja sales promotion dengan memperhatikan beban kerja dari sales promotion melaui pemberian motivasi, karena menunjukkan bahwa motivasi dapat mempengaruhi hubungan pengaruh beban kerja terhadap kinerja sales promotion. Untuk meningkatkan kinerja para sales promotion sebaiknya ditingkatkan oleh pihak manajemen dengan cara memperhatikan tingkat dari beban kerja para sales promotion karena kondisi karyawan yang mempunyai beban kerja tinggi akan berdampak pada emosi, jalan pikiran, dan kondisi fisik seseorang sehingga karyawan sales promotion tidak bisa bekerja secara optimal dalam mencapai target kinerja. Selain dari beban kerja, upaya yang dapat dilakukan oleh perusahaan dalam meningkatkan kinerja sales promotion yaitu melalui peningkatan motivasi kerja. Dengan motivasi yang tinggi akan membuat karyawan lebih semangat dan terpacu untuk dapat menyelesaikan pekerjaan yang ditentukan oleh perusahaan.(2) Bagipenelitiselanjutnyayangtertarikuntuk mengkaji aspek yangserupa yaitubeban kerja, kinerja dan motivasi diharapkanuntuk mengembangkan penelitian ini dengan menggunakan dimensi dan indikator yang lebih luas agar hasil penelitian lebih teruji keandalannya,disamping itu juga diharapkan untuk menguji variabel lain yang diduga kuat dapat mempengaruhi kinerja karyawan seperti kompensasi, pengembangan karir, lingkungan kerja, kepemimpinan, pelatihan,kompetensi, kompensasi, dan komitmen individu.

\section{Daftar Pustaka}

Adinugroho, Julio. 2017. Pengaruh Beban Kerja terhadap Motivasi Kerja di Rumah makan Cahaya Mas. Manajemen. Fakultas Ekonomi. Universitas Katolik Parahyangan Bandung.

Anita, Aziz, dan Yunus. 2013 Pengaruh Penempatan Dan Beban Kerja Terhadap Motivasi Kerja Dan Dampaknya Pada Prestasi Kerja Pegawai Dinas Tenaga Kerja Dan Mobilitas Penduduk Aceh. Jurnal manajemen, Vol 2 No.1 : 70. 
Ayun, Qurrotun. 2011. Penilaian Kerja (Performonce Appraisal) Pada Karyawan di Perusahaan. Jurnal Informatika, Vol. 2, No. 3.

Bagia,I Wayan.2005.PengaruhModallntelektual,danKepuasanKerjaterhadap Kinerja Pegawai PemerintahDaerahKabupatendi ProvinsiBali.Desertasi Doktor dalamllmuEkonomiUniversitas Padjajaran(tidakditerbitkan). Bandung.

Bagia, I Wayan. 2015. Perilaku Organisasi. Yogyakarta: Graha Ilmu.

Ghozali, Imam, 2005. Aplikasi Analisis Multivariate dengan program SPPS, Edis Ketiga. Penerbit Penerbit Universitas Diponegoro, Semarang.

Ghozali, Imam. 2011. Aplikasi Analisis Multivariate dengan Program SPSS. Semarang: Badan Penerbit Universitas Diponegoro.

Irawati, Rusda, dan Arimbi Carollina, Dini. 2017. Analisis Pengaruh Beban KErja Terhadap Kinerja Karyawan Operator Pada PT Giken Precision Indosesia, Administrasi Bisnis Terapan. Politeknik Negeri Batam. Kepulauan Riau.

Hasibuan,Malayu.S.P.2001. Manajemen:Dasar,PengertiandanMasalah. Jakarta: Bumi Aksara. 2012.ManajemanSumberDayaManusia.EdisiRevisi.Jakarta:PTBumi Aksara.

Kasmir. 2016. Manajemen Sumber Daya Manusia (Teori Dan Praktik). Cetakan Ke-1 Jakarta : PT. Raja Grafindo Persada.

M, Irzal. 2016 Dasar-Dasar Kesehatan Dan Keselamatan Kerja. Jakarta : Kencana.

Mangkunegara, Anwar Prabu. 2006. Manajemen Sumber Daya Manusia Perusahaan. Bandung: PT. Remaja Rosdakarya.

Manuaba. 2000. Hubungan Beban Kerja Dan Kapasitas Kerja. Jakarta: Rinek Cipta.

Morgan, Michael, 1993, Strategi Inovasi Sumber Daya Manusia, Terjemahan Palupi Tyas R., PT Elex Media Komputindo, Jakarta.

Nani, Usri dan Kustiani, Lilik. 2012. Pengaruh motivasi kerja terhadap kinerja karyawan PT. Kebon Agung Malang.Jurnal manajemen, Vol. 8, No 2

Rai, Agung. 2008. Audit Kinerja pada Sektor Publik . Jakarta: Selemba Empat.

Ratna, Dewi. 2015. "Pengaruh Tingkat Pendidikan dan Motivasi Kerja Terhadap Kinerja karyawan".Jurnal Manajemen.Volume 2 Tahun 2015 (hlm 4).

Rivai, Veithzal dan Sagala, Ella Jauvani. 2013. Manajemen Sumber Daya Manusia Untuk Perusahaan Dari Teori Ke Praktik. Jakarta: PT Raja Grafindo Persada.

Sunyoto, Danang. 2012. Manajemen Sumber Daya Manusia. Jakarta: PT. Buku Seru

Putra, A. S. 2012. Analisis Pengaruh Beban Kerja Terhadap Kinerja Karyawan Divisi Marketing dan Kredit PT. WOM Finance Cabang Depok. Skripsi. Institut Pertanian Bogor.

Widodo, suparno eko. 2015. Manajemen Pengembangan Sumber Daya Manusia. Yogyakarta : Penerbit Pustaka Pelajar. 